\title{
KAJIAN USAHATANI PADI SAWAH DI DESA TOMBATU TIGA TIMUR KECAMATAN TOMBATU KABUPATEN MINAHASA TENGGARA
}

\author{
Anastasio A. J. Waleleng \\ Jenny Baroleh \\ Tommy F. Lolowang
}

\begin{abstract}
This study aims to determine farmer's income of rice farming in Eastern Tombatu 3, Tombatu Village, Southeast Minahasa District. This Study take for March to May 2018. Primary data obtained from interview using questionnaires to 5 respondent based on Simplen Random Sampling method, because the respondent homogeneous. Data analyzed used income and cost analysiss, culculated using $R / C$ Ratio. The result showed that the average income of the rice farmers in The Eastern Tombatu 3 Village Rp. 2,033,928 with an R/C Ratio 1,43. It means rice farming in Eastern Tombatu 3 Village Southeast Minahasa District profitable and worth the effort. *lwths*.
\end{abstract}

Keywords: $\quad$ study of farming, rice paddy, Eastern Tombatu 3 Village, Tombatu Sub-District, Southeast Minahasa District

\begin{abstract}
ABSTRAK
Penelitian ini bertujuan untuk mengetahui tingkat pendapatan petani dalam usahatani padi sawah di Desa Tombatu Tiga Timur, Kecamatan Tombatu, Kabupaten Minahasa Tenggara. Penelitian berlangsung selama tiga bulan dari Maret sampai Mei 2018. Data primer di peroleh melalui wawancara dan menggunakan kuesioner kepada 5 orang responden yang ada di Desa Tombatu Tiga Timur yang diperoleh berdasarkan luas lahan panen. penentuan sampel berdasarkan metode simple randam sampling (secara acak) karena homogen. Analisis data yang digunakan yaitu analisis pendapatan dan biaya yang dihitung dengan R/C Ratio. Hasil penelitian menunjukkan bahwa pendapatan rata-rata petani padi sawah di Desa Tombatu Tiga Timur Kecamatan Tombatu yaitu Rp. 2,033,928, dengan nilai R/C Ratio yang di dapat lebih dari 1, yaitu 1.43 yang berarti usahatani padi sawah di Desa Tombatu Tiga Timur Kecamatan Tombatu menguntungkan sehingga layak untuk di usahakan. *lwths*.
\end{abstract}

Kata kunci: kajian usahatani, padi sawah, Desa Tombatu Tiga Timur, Kecamatan Tombatu, Kabupaten Minahasa Tenggara

\section{PENDAHULUAN}

\section{Latar Belakang}

Pembangunan pada sektor pertanian merupakan kebutuhan pokok berupa bahan pangan utama khususnya beras semakin lama semakin meningkat sesuai dengan laju pertumbuhan penduduk dan perkembangan kondisi perekonomian masyarakat. Tanaman pangan yang banyak diusahakan oleh rumah tangga petani di Indonesia adalah padi sebagai penghasil beras. Di Indonesia, beras merupakan mata dagangan yang sangat panting, sebab beras merupakan bahan makanan pokok dan merupakan sumber kalori bagi sebagian penduduk. Sebagian masyarakat masih tetap menghendaki agar pasokan beras tersedia sepanjang waktu, distribusi secara merata dan harganya stabil serta terjangkau.

Salah satu komoditas pertanian yang diharapkan dapat bergerak positif dalam hal peningkatan produksi dan pendapatannya adalah padi. Beberapa alasan penting keberlanjutan produksi padi perlu untuk dijaga yakni:

(a) beras merupakan bahan pangan pokok bagi masyarakat Indonesia, (b) merupakan 
komoditas penting untuk menjaga ketahanan pangan, (c) usahatani padi sudah merupakan bagian hidup dari petani Indonesia sehingga menciptakan lapangan kerja yang besar, (d) kontribusi dari usahatani padi terhadap pendapatan rumah tangga cukup besar (Hamdan, 2013).

Sekitar $90 \%$ penduduk Indonesia menggunakan beras sebagai bahan pangan pokok karena beras dapat menyumbangkan $40-80 \%$ kalori dan $45-55 \%$ protein. Sumbangan beras dalam mengisi lapisan kebutuhan gizi tersebut makin besar pada lapisan penduduk berpenghasilan rendah (Koswara, 2009).

Kebutuhan pangan masyarakat di Indonesia sebesar 96,09\% didapat dari mengkonsumsi beras, dengan demikian aspek sistem usaha pertanian tanaman pangan sangat diperlukan. Hal tersebut guna mendapatkan gambaran yang lebih detil terhadap usaha petani padi sawah sebagai produsen beras, yang sangat mempengaruhi ketersediaan pangan di Indonesia. Usahatani padi berkaitan dengan dua hal yaitu dari sisi penerimaan dan dari sisi pembiayaannya. Komponen biaya usahatani pada umumnya terdiri dari biaya sarana produksi, upah tenaga kerja, dan biaya lainnya. (Arsyad dan Rustiadi, 2008). Berdasarkan data kantor camat keseluruhan luas wilayah Desa Tombatu Tiga Timur $\pm 30,47$ ha dan memiliki luas lahan sawah 8,30 ha.

Komoditas padi sawah merupakan sumber pendapatan dari sebagian besar penduduk di Desa Tombatu Tiga Timur Kecamatan Tombatu, disamping komoditas lainnya.

\section{Rumusan Masalah}

Bagaimana kondisi usahatani padi sawah di Desa Tombatu Tiga Timur Kecamatan Tombatu, mulai tahap kegiatan persemaian sampai kegiatan produksi?

\section{Tujuan Penelitian}

Penelitian ini bertujuan untuk mengetahui tingkat pendapatan petani dalam usahatani padi sawah di Desa Tombatu Tiga Timur Kecamatan Tombatu Kabupaten Minahasa Tenggara.

\section{Manfaat Penelitian}

Sebagai tambahan ilmu untuk petani, pemerintah dan peneliti mengenai usahatani padi sawah serta dapat menjadi bahan referensi bagi penelitian selanjutnya.

\section{METODE PENELITIAN}

\section{Waktu Penelitian}

Penelitian ini berlangsung selama tiga bulan yaitu dari bulan Maret sampai Mei 2018, sejak dari tahap persiapan, sampai penyusunan laporan hasil. Penelitian dilaksanakan di Desa Tombatu Tiga Timur Kecamatan Tombatu Kabupaten Minahasa Tenggara.

\section{Metode Penentuan Sampel}

Pengambilan sampel dilakukan dalam dua tahap. Pertama adalah menentukan sampel desa yang dilakukan secara purposive sampling (sengaja). Usahatani padi sawah di Desa Tombatu Tiga Timur bersifat homogen,. Kedua adalah menentukan petani sampel. Petani sampel ditetapkan dengan munggunakan metode simple random sampling (acak sederhana). Dalam penelian ini jumlah petani sampel yang di ambil sebanyak 5 petani sampel, dilihat dari total luas lahan yang kecil.

\section{Metode Pengumpulan Data}

Data yang dikumpulkan meliputi data primer dan data sekunder. Data primer diperoleh dengan pengamatan dan wawancara langsung dengan petani dalam bentuk kuisioner. Data sekunder dikumpulkan melalui buku, arsip dan laporan yang terkumpul pada kantor-kantor instansi pemerintah kecamatan.

\section{Konsep Pengukuran Variabel}

Variabel-variabel yang diukur dalam penelitian ini adalah:

1. Karakteristik petani responden meliputi :
a. Umur (tahun)
b. Tingkat pendidikan
c. Jumlah anggota keluarga (orang)
d. Status pengusahaan lahan
e. Lama pengusahaan lahan 
2. Luas tanam usahatani, yaitu luas lahan sawah yang digarap oleh petani untuk menghasilkan padi dan diukur dalam satuan hektar (ha)

3. Produksi padi, yaitu jumlah produksi yang dihasilkan oleh setiap petani selama satu musim tanam dan dinyatakan dalam jumlah (per-sak)

4. Sarana produksi yang digunakan, seperti bibit, pupuk dan pestisida

5. Peralatan yang digunakan, seperti, parang, alat pembajak dan sabit/mesin pemotong.

6. Harga jual, yaitu harga padi sawah yang dijual oleh petani (rupiah)

7. Biaya adalah semua pengeluaran dalam satu kali proses produksi (masa tanam), meliputi:

a. Biaya tetap, terdiri dari :

- Biaya penyusutan peralatan

b. Biaya tidak tetap (variable), terdiri dari :

- $\quad$ Biaya tenaga kerja (Rp/HOK)

- Biaya sarana produksi (rupiah

8. Penerimaan adalah banyaknya atau besarnya jumlah yang terjual, diperoleh melalui jumlah perkalian antara produksi dengan harga jual (rupiah)

9. Pendapatan usahatani padi sawah adalah seluruh pendapatan yang diperoleh hanya dari usahatani padi sawah.

\section{Analisis Data}

Data yang diperoleh dalam penelitian ini dianalisis dengan menggunakan metode analisis deskriptif dengan bantuan tabel dan untuk mengetahui besarnya pendapatan yang diperoleh menggunakan rumus:

$$
\mathrm{FI}=\mathrm{TR}-\mathrm{TC}
$$

Keterangan:

FI = Pendapatan Usahatani

TR $=$ Total Penerimaan

$\mathrm{TC}=$ Total Biaya

Untuk mengetahui kelayakan usahatani, maka digunakan rumus Analisis Return Cost Ratio.

Keterangan :

$$
\mathrm{a}=\mathrm{R}: \mathrm{C}
$$

$\mathrm{a}=$ Return Cost Ratio

$R=$ Return (Penerimaan)

$\mathrm{C}=\operatorname{Cost}($ Biaya)

Apabila:

$\mathrm{R} / \mathrm{C}=1$, usahatani tidak untung dan tidak rugi

$\mathrm{R} / \mathrm{C}<1$, usahatani rugi

$\mathrm{R} / \mathrm{C}>1$, usahatani untung

\section{HASIL DAN PEMBAHASAN}

\section{Deskripsi Wilayah Penelitian}

Tombatu Tiga Timur merupakan salah satu desa yang ada di Kecamatan Tombatu Kabupaten Minahasa Tenggara yang memiliki batas wilayah sebagai berikut:

Dengan batas wilayah sebagai berikut:

Utara : Desa Tombatu Tiga

Timur : Desa Kuyanga

Selatan : Desa Tombatu

Barat : Desa Tombatu Tiga Tengah dan Desa

Tombatu Tiga Selatan

Letak Geografis Desa Tombatu Tiga Timur antara $1^{\circ} 02^{\prime} 21.08^{\prime \prime}$ Lintang Utara dan $124^{\circ} 41^{\prime 2} 23.34^{\prime \prime}$ Bujur Timur . Luas wilayah Desa ini adalah 30.47 ha dimana luas lahan persawahan 8.30 hektar.

\section{Luas Lahan Petani padi sawah}

Luas lahan merupakan penentu dari pengaruh faktor produksi padi sawah. Semakin luas lahan yang digarapi/ditanam maka semakin besar jumlah produksi yang di dapat oleh petani padi sawah.

Tabel 1 menunjukkan bahwa luas lahan padi sawah yang dimiliki setiap petani padi sawah. Dengan total penggunaan luas lahan petani padi sawah sebesar 1.95 ha. Luasa lahan yang hanya di bawah 1 ha dikarenakan rata-rata luas lahan yang dimiliki petani padi sawah di bawah 0,5 ha.

Tabel 1. Luas Lahan Petani Padi Sawah

\begin{tabular}{ccr}
\hline Responden & Luas Lahan (ha) & Persentase (\%) \\
\hline 1 & 0.50 & 25.64 \\
2 & 0.50 & 25.64 \\
3 & 0.40 & 20.51 \\
4 & 0.30 & 15.38 \\
5 & 0.25 & 12.82 \\
\hline Total & 1.95 & 100.00 \\
\hline Sumber : Olahan Data Primer, 2018
\end{tabular}

\section{Status Kepemilikan Lahan}

Lahan sebagai salah satu faktor produksi yang mempunyai kontribusi cukup besar terhadap usahatani. Status kepemilikan lahan juga menentukan besar kecilnya biaya yang akan dikeluarkan untuk pembiayaan lahan tersebut.

Berdasarkan hasil wawancara bahwa status kepemilikan lahan petani padi sawah secara menyeluruh (100\%) adalah lahan milik sendiri.

Agrisosioekonomi: 


\section{Persemaian}

Persemaian merupakan hal penting dalam budidaya padi sawah. Beberapa faktor yang mempengaruhi pertumbuhan tanaman terletak pada persemaian yang di persiapkan yaitu jenis tanaman serta varietas tanaman yang tentu harus unggul dan bagus untuk di tanam. Terutama pada budidaya padi varietas yang unggul tahan terhadap hama dan penyakit.

Tabel 2 menunjukkan bahwa Luas persemaian atau pembenihan adalah 0,0041 dari luas lahan yang digunakan dalam penanaman padi.

Tabel 2. Luas Areal Tanam Persemaian Petani Padi Tabel 2. Luas A

\begin{tabular}{cr}
\hline Responden & Luas Lahan Persemaian $\left(\mathbf{m}^{\mathbf{2}}\right)$ \\
\hline 1 & 0.0012 \\
2 & 0.0011 \\
3 & 0.0008 \\
4 & 0.0006 \\
5 & 0.0004 \\
\hline Total & 0.0041 \\
\hline
\end{tabular}

Sumber : Olahan Data Primer, 2018

Tabel 3 menunjukkan bahwa rata-rata penggunaan benih sebanyak $8,56 \mathrm{~kg}$. Varietas Benih yang digunakan oleh petani padi yaitu cigeulis dan Superwin, Sebagian besar menggunakan cigeulis karena rasanya yang enak, hasil buah yang dihasilkan banyak dan tahan terhadap beberapa jenis hama dan penyakit.

Tabel 3. Varietas dan Jumlah Benih

\begin{tabular}{clcrc}
\hline \multirow{2}{*}{ Responden } & $\begin{array}{c}\text { Varietas } \\
\text { Benih }\end{array}$ & $\begin{array}{c}\text { Pemakaia } \\
(\mathbf{K g})\end{array}$ & Harga (Rp) & Total Biaya (Rp) \\
\hline 1 & Cigeulis & 9.41 & 4,935 & 46,438 \\
2 & Cigeulis & 10.82 & 4,935 & 53,397 \\
3 & cigeulis & 7.05 & 4,935 & 34,792 \\
4 & Superwin & 9.41 & 5,347 & 50,315 \\
5 & Cigeulis & 6.11 & 4,935 & 30,153 \\
\hline Rata-rata & & 8.56 & 5,017 & 43,019 \\
\hline
\end{tabular}

\section{Pengolahan Lahan}

Pengolahan lahan dilakukan untuk membuat struktur tanah menjadi lunak agar dapat digunakan untuk penanaman padi.

Petani padi sawah di Desa Tombatu Tiga Timur melakukan pengolahan lahan dengan menggunakan mesin traktor, dikarenakan waktu yang diperlukan dalam pengolahan lahan menggunakan mesin traktor relatif lebih cepat dari pada menggunakan tenaga hewan maupun tenaga manusia. Selain itu biaya yang dikeluarkan tidak terlalu mahal dibanding menggunakan tenaga hewan ataupun tenaga manusia.

Tabel 4 menunjukkan bahwa biaya sewa traktor petani padi sawah di Desa Tombatu Tiga Timur sebesar Rp 600.000 per 0,5 hektar. Dengan biaya rata-rata sewa traktor sebesar Rp 480.000 .

Tabel 4. Biaya Pengolahan Lahan Padi Sawah

\begin{tabular}{ccc}
\hline Responden & Jenis Alat & Biaya (Rp) \\
\hline 1 & traktor & $600,000.00$ \\
2 & traktor & $600,000.00$ \\
3 & traktor & $500,000.00$ \\
4 & traktor & $400,000.00$ \\
5 & traktor & $300,000.00$ \\
\hline Rata-rata & & $480,000.00$ \\
\hline \multicolumn{2}{l}{ Sumber : Olahan Data Primer, 2018 }
\end{tabular}

\section{Penanaman}

Penanaman menggunakan sistem penanaman jajar legowo, yaitu sistem tanam yang menggunakan jarak tanam yang tidak sama antar jarak dalam barisan dengan jarak antar barisan.

Tabel 5 menunjukkan bahwa semua petani padi sawah sudah menggunakan sistem penanaman jajar legowo, karena sistem jajar legowo lebih hemat dalam pemupukan maupun dalam penyemprotan. Karena daya jangkau langsung mengarah pada tanaman padi sawah.

\section{Tabel 5. Sistem Penanaman Padi Sawah}

\begin{tabular}{cccc}
\hline Responden & $\begin{array}{c}\text { Sistem } \\
\text { Penanaman }\end{array}$ & $\begin{array}{c}\text { Ukuran } \\
\text { Jarak Tanam } \\
(\mathbf{c m})\end{array}$ & $\begin{array}{c}\text { Perbandingan } \\
\text { Tiap Jarak } \\
\text { Tanam (Cm) }\end{array}$ \\
\hline 1 & Jajar legowo & $25 \times 25$ & $4: 30$ \\
2 & Jajar legowo & $25 \times 25$ & $5: 35$ \\
3 & Jajar legowo & $25 \times 25$ & $5: 40$ \\
4 & Jajar legowo & $20 \times 20$ & $4: 35$ \\
5 & Jajar legowo & $20 \times 20$ & $5: 30$ \\
\hline Sumber: Olahan Data Primer, 2018 &
\end{tabular}

\section{Pemupukan}

Dalam usahatani padi sawah di Desa Tombatu Tiga Timur Petani padi sawah melakukan pemupukan dengan menggunakan pupuk kimia. 
Tabel 6 menunjukkan bahwa pemupukan padi sawah di lakukan secara bertahap sebanyak 3 kali pemupukan. Pemupukan pertama saat padi berumur 14 (HST), kemudian setelah padi berumur antara 20- 25 (HST) di lakukan pemupukan kembali. Dan pemupukan terakhir saat padi dikatakan bunting muda atau pada 3040 HST. Takaran dalam setiap kali pemupukan di ukur dengan cara, total pupuk yang akan di gunakan di bagi dengan tiga kali pemupukan.

Tabel 6. Penggunaan Pupuk Berdasarkan Jenis, Jumlah dan Harga

\begin{tabular}{|c|c|c|c|c|c|}
\hline Responden & $\begin{array}{c}\text { Luas } \\
\text { Lahan } \\
\text { (Ha) }\end{array}$ & $\begin{array}{c}\text { Jenis } \\
\text { Pupuk }\end{array}$ & $\underset{(\mathrm{Kg})}{\text { Pemakaian }}$ & Harga (Rp) & $\begin{array}{l}\text { Total Biaya } \\
\quad \text { (Rp) }\end{array}$ \\
\hline \multirow[t]{2}{*}{1} & 0.5 & Ponska & 100 & $2,500.00$ & $350,000.00$ \\
\hline & & Urea & 50 & $2,000.00$ & \\
\hline \multirow[t]{3}{*}{2} & 0.5 & SP36 & 50 & $2,500.00$ & $350,000.00$ \\
\hline & & Ponska & 50 & $2,500.00$ & \\
\hline & & Urea & 50 & $2,000.00$ & \\
\hline \multirow[t]{3}{*}{3} & 0.4 & SP36 & 50 & $2,500.00$ & $350,000.00$ \\
\hline & & Urea & 50 & $2,000.00$ & \\
\hline & & Ponska & 50 & $2,500.00$ & \\
\hline \multirow[t]{2}{*}{4} & 0.3 & SP36 & 50 & $2,500.00$ & $225,000.00$ \\
\hline & & Urea & 50 & $2,000.00$ & \\
\hline \multirow[t]{2}{*}{5} & 0.25 & Ponska & 100 & $2,500.00$ & $350,000.00$ \\
\hline & & Urea & 50 & $2,000.00$ & \\
\hline Rata-rata & & & 58.33 & $2,292.00$ & $325,000.00$ \\
\hline
\end{tabular}

Sumber : Olahan Data Primer, 2018

\section{Pestisida}

Pestida digunakan agar tanaman usahatani padi sawah terhindar dari hama dan penyakit dengan penggunaan dosis yang tepat tergantung dari jenis hama dan penyakit.

Tabel 7 menunjukkan bahwa jumlah penggunaan pestida bermacam-macam serta harga pestisida yang berbeda tergantung dari jenis pestisida yang digunakan oleh petani padi sawah.

Tabel 7. Penggunaan Pestisida Berdasarkan Jenis, Jumlah dan Harga

\begin{tabular}{|c|c|c|c|c|}
\hline Responden & $\begin{array}{l}\text { Jenis } \\
\text { Obat }\end{array}$ & $\begin{array}{c}\text { Pemakaian } \\
\text { (Botol) }\end{array}$ & Harga (Rp) & $\begin{array}{c}\text { Total } \\
\text { Biaya } \\
(\mathbf{R p}) \\
\end{array}$ \\
\hline \multirow[t]{2}{*}{1} & Dursban & 2 & $40,000.00$ & $280,000.00$ \\
\hline & spontan & 2 & $100,000.00$ & \\
\hline \multirow[t]{2}{*}{2} & Dursban & 1 & $40,000.00$ & $440,000.00$ \\
\hline & Spontan & 4 & $100,000.00$ & \\
\hline \multirow[t]{2}{*}{3} & Decis & 5 & $28,000.00$ & $355,000.00$ \\
\hline & Virtako & 1 & $215,000.00$ & \\
\hline 4 & Decis & 5 & $28,000.00$ & $140,000.00$ \\
\hline \multirow[t]{2}{*}{5} & Dursban & 3 & $40,000.00$ & $232,000.00$ \\
\hline & Kempo & 2 & $56,000.00$ & \\
\hline Rata-rata & & 2.8 & $71,888.89$ & $289,400.00$ \\
\hline
\end{tabular}

Tabel 8 sampai Tabel 10 menunjukkan bahwa tenaga kerja yang di gunakan dalam usahatani padi sawah berasal dari tenaga kerja dalam keluarga dan tenaga kerja luar keluarga, dengan perbedaan penggunaan tenaga kerja setiap petani padi sawah maka berbeda pula biaya yang di keluarkan masigmasing petani untuk tenaga kerja.

Tabel 8. Biaya Tenaga Kerja Penanaman Padi Sawah

\begin{tabular}{cccccl}
\hline \multicolumn{5}{c}{ Jumlah Tenaga Kerja } \\
\hline Responden & $\begin{array}{c}\text { Dalam } \\
\text { Keluarga } \\
\text { (DK) }\end{array}$ & $\begin{array}{c}\text { Luar } \\
\text { Keluarga } \\
\text { (LK) }\end{array}$ & $\begin{array}{c}\text { Biaya/ } \\
\text { Hari } \\
\text { (Rp) }\end{array}$ & $\begin{array}{c}\text { Hari } \\
\text { Orang } \\
\text { Kerja } \\
\text { (HOK) }\end{array}$ & $\begin{array}{l}\text { Biaya } \\
(\text { Rp) }\end{array}$ \\
\hline 1 & 1 & 14 & 150,000 & 1 & $2,100,000$ \\
2 & - & 15 & 150,000 & 1 & $2,250,000$ \\
3 & 1 & 5 & 150,000 & 2 & $1,500,000$ \\
4 & - & 15 & 150,000 & 1 & $2,250,000$ \\
5 & 1 & 5 & 150,000 & 1 & 750,000 \\
\hline Rata-rata & 1 & 10.80 & 150,000 & 1.20 & $1,770,000$ \\
\hline Sumber : Olahan Data Primer, 2018 & \multicolumn{7}{l}{}
\end{tabular}

\begin{tabular}{cccccl}
\multicolumn{6}{c}{ Tabel 9. Biaya Tenaga Kerja Pemeliharaan Padi Sawah } \\
\hline \multicolumn{5}{c}{ Jumlah Tenaga Kerja } \\
\hline Responden & $\begin{array}{c}\text { Dalam } \\
\text { Keluarga } \\
\text { (DK) }\end{array}$ & $\begin{array}{c}\text { Luar } \\
\text { Keluarga } \\
\text { (LK) }\end{array}$ & $\begin{array}{c}\text { Biaya/ } \\
\text { Hari } \\
\text { (Rp) }\end{array}$ & $\begin{array}{c}\text { Hari } \\
\text { Orang } \\
\text { Kerja } \\
\text { (HOK) }\end{array}$ & $\begin{array}{l}\text { Biaya } \\
\text { (Rp) }\end{array}$ \\
\hline 1 & 2 & 1 & 125,000 & 1 & 125,000 \\
2 & 1 & 2 & 125,000 & 1 & 250,000 \\
3 & 1 & 125,000 & 1 & 125,000 \\
4 & 1 & 3 & 125,000 & 1 & 375,000 \\
5 & 1.33 & 1.75 & 125,000 & 1 & 218,750 \\
\hline Rata-rata & 1 & 125,000 & 1 & \\
\hline
\end{tabular}

Sumber : Olahan Data Primer, 2018

Tabel 10. Biaya Tenaga Kerja Panen Padi Sawah

\begin{tabular}{cccccl}
\hline \multicolumn{5}{c}{ Jumlah Tenaga Kerja } \\
\hline Responden & $\begin{array}{c}\text { Dalam } \\
\text { Keluarga } \\
(\mathbf{D K})\end{array}$ & $\begin{array}{c}\text { Luar } \\
\text { Keluarga } \\
(\mathbf{L K})\end{array}$ & $\begin{array}{c}\text { Biaya/ } \\
\text { Hari } \\
(\mathbf{R p})\end{array}$ & $\begin{array}{c}\text { Hari } \\
\text { Orang } \\
\text { Kerja } \\
(\text { HOK) }\end{array}$ & $\begin{array}{l}\text { Biaya } \\
(\mathbf{R p})\end{array}$ \\
\hline 1 & 1 & 14 & 150,000 & 1 & $2,100,000$ \\
2 & 1 & 15 & 150,000 & 1 & $2,250,000$ \\
3 & 1 & 5 & 150,000 & 2 & $1,500,000$ \\
4 & 1 & 5 & 150,000 & 1 & $2,250,000$ \\
5 & 1 & 150,000 & 1 & 750,000 \\
\hline Rata-rata & 1 & 10.80 & 150,000 & 1.20 & $1,770,000$ \\
\hline Sumber: Olahan Data Primer, 2018
\end{tabular}

\section{Biaya Penyusutan}

Biaya penyusutan adalah biaya pengurangan nilai akibat pemakaian alat selama proses produksi. Masa pakai alat di hitung dalam 1 musim tanam yaitu empat bulan. Rumus biaya penyusutan peralatan adalah sebagai berikut:

$$
\frac{\text { Masa Pakai Alat }}{\text { Umur Alat }} x \text { Harga Barang }
$$


Tabel 11. Biaya Penyusutan Alat

\begin{tabular}{ccccc}
\hline Responden & Parang & Cangkul & $\begin{array}{c}\text { Tangki } \\
\text { Semprot }\end{array}$ & $\begin{array}{c}\text { Biaya } \\
(\mathbf{R p})\end{array}$ \\
\hline 1 & 11,333 & 5,667 & 13,333 & 30,333 \\
2 & 12,667 & 4,667 & 16,667 & 34,001 \\
3 & 14,667 & 5,000 & 11,333 & 31,000 \\
4 & 10,000 & 4,667 & 12,333 & 27,000 \\
5 & 11,000 & 4,667 & 16,667 & 32,334 \\
\hline \multicolumn{5}{l}{ Sumber : Olahan Data Primer, 2018 }
\end{tabular}

\section{Total Biaya Usahatani}

Total biaya yang di keluarkan dalam proses produksi usahatani padi sawah termasuk didalamnya barang yang dibeli dalam 1 musim tanam.

Tabel 12 dan Tabel 13 menunjukkan bahwa rata-rata total biaya usahatani dari keseluruhan biaya produksi selama satu musim tanam adalah Rp. 4,847,419.00. sedangkan total biaya usahatani perhektar adalah Rp. 12,955,142 Semakin besar penggunaan satuan produksi maka akan semakin besar pula biaya yang akan dikeluarkan.

Tabel 14 menunjukkan bahwa jumlah produksi yaitu total Gabah Kering Giling (GKG) yang di dapat berdasarkarkan dari setiap jumlah luas lahan petani padi sawah, dan produkstivitas adalah total Gabah Kering Giling (GKG) yang di dapat dari hasil produksi perhektar.

Tabel 12. Total Biaya Usahatani Padi sawah

\begin{tabular}{|c|c|c|c|c|c|c|}
\hline Responden & $\begin{array}{c}\text { Benih } \\
\text { (Rp) }\end{array}$ & $\begin{array}{c}\text { Pupuk } \\
\text { (Rp) }\end{array}$ & $\begin{array}{l}\begin{array}{l}\text { Obat- } \\
\text { obatan } \\
\text { (Rp) }\end{array} \\
\end{array}$ & $\begin{array}{c}\text { Tenaga } \\
\text { Kerja } \\
(\mathbf{R p}) \\
\end{array}$ & $\begin{array}{c}\text { Pengolahan } \\
\text { Lahan } \\
\text { (Rp) }\end{array}$ & $\begin{array}{c}\text { Total } \\
\text { Biaya } \\
\text { (TC) }(\mathrm{Rp}) \\
\end{array}$ \\
\hline 1 & 46,438 & 350,000 & 280,000 & $4,325,000$ & 600,000 & $5,601,438$ \\
\hline 2 & 53,397 & 350,000 & 440,000 & $4,750,000$ & 600,000 & $6,193,397$ \\
\hline 3 & 34,792 & 350,000 & 355,000 & $3,125,000$ & 500,000 & $4,364,792$ \\
\hline 4 & 50,315 & 225,000 & 140,000 & $4,850,000$ & 400,000 & $5,665,315$ \\
\hline 5 & 30,153 & 350,000 & 232,000 & $1,500,000$ & 300,000 & $2,412,153$ \\
\hline Rata-rata & 43,019 & 325,001 & 289,400 & $3,710,000$ & $2,663,710$ & $4,847,419$ \\
\hline
\end{tabular}

Tabel 13. Biaya Usahatani Berdasarkan Luas Lahan

\begin{tabular}{ccr}
\hline Responden & Luas Lahan $(\mathbf{H a})$ & Total Biaya/Ha $(\mathbf{R p})$ \\
\hline 1 & 0.50 & $11,202,876$ \\
2 & 0.50 & $12,386,794$ \\
3 & 0.40 & $10,911,980$ \\
4 & 0.30 & $18,884,383$ \\
5 & 0.25 & $11,389,676$ \\
\hline Rata-rata & & $12,955,142$ \\
\hline Sumber : Olahan Data Primer, 2018 &
\end{tabular}

\begin{tabular}{cccc} 
Tabel 14. Jumlah Produksi dan Produktivitas Usahatani Padi Sawah \\
\hline Responden & $\begin{array}{c}\text { luas lahan } \\
\text { (Ha) }\end{array}$ & $\begin{array}{c}\text { Jumlah } \\
\text { Produksi } \\
\text { (Kg) }\end{array}$ & $\begin{array}{c}\text { Produktivitas } \\
\text { (/Ha) }\end{array}$ \\
\hline 1 & 0.50 & 1,800 & 3,600 \\
2 & 0.50 & 1,680 & 3,360 \\
3 & 0.40 & 1,380 & 3,450 \\
4 & 0.30 & 1,200 & 4,000 \\
5 & 0.25 & 900 & 3,600 \\
\hline Rata-rata & & 1,392 & 3,602 \\
\hline
\end{tabular}

Sumber : Olahan Data Primer, 2018

\section{Total Penerimaan Usahatani}

Penerimaan adalah hasil yang di dapatkan dari hasil produksi usahatani padi sawah yang ada di Desa Tombatu Tiga Timur, berdasarkan luas lahan dari setiap petani padi sawah.

Tabel 15 dan 16 menunjukkan bahwa penerimaan dari setiap petani padi sawah berbeda-beda dikarenakan perbedaan luas lahan produksi, semakin besar penggunaan luas lahan produksi usahatani maka akan semakin besar pula total produksi yang akan di terima oleh petani.

Semakin besar jumlah produksi yang di hasilkan oleh petani padi sawah maka akan semakin besar pula jumlah penerimaan yang akan di dapat oleh petani padi sawah. Peningkatan luas lahan juga akan mempengaruhi jumlah penerimaan. Harga jual pun menentukan jumlah penerimaan yang akan di terima oleh masing-masing petani padi sawah.

Tabel 15. Penerimaan Berdasarkan Luas Lahan

\begin{tabular}{cccc}
\hline Responden & $\begin{array}{c}\text { luas } \\
\text { lahan } \\
(\mathbf{H a})\end{array}$ & $\begin{array}{c}\text { Jumlah } \\
\text { Produksi } \\
(\mathbf{K g})\end{array}$ & $\begin{array}{c}\text { Total } \\
\text { penerimaan } \\
(/ \mathbf{H a})\end{array}$ \\
\hline 1 & 0.50 & 3,600 & $17,766,000$ \\
2 & 0.50 & 3,360 & $16,581,600$ \\
3 & 0.40 & 3,450 & $17,025,750$ \\
4 & 0.30 & 4,000 & $21,388,000$ \\
5 & 0.25 & 3,600 & $17,766,000$ \\
\hline Rata-rata & & 3,602 & $18,105,470$ \\
\hline
\end{tabular}

Tabel 16. Penerimaan Dalam Satu Kali Musim Tanam

\begin{tabular}{cccc}
\hline Responden & $\begin{array}{c}\text { Jumlah } \\
\text { Produksi } \\
(\mathbf{K g})\end{array}$ & $\begin{array}{c}\text { Harga Gabah } \\
\text { Kering Giling } \\
(\mathbf{G K G})(\mathbf{R p})\end{array}$ & $\begin{array}{c}\text { Total } \\
\text { Penerimaan } \\
(\mathbf{R p})\end{array}$ \\
\hline 1 & 1,800 & 4,935 & $8,883,000$ \\
2 & 1,680 & 4,935 & $8,290,800$ \\
3 & 1,380 & 4,935 & $6,810,300$ \\
4 & 1,200 & 5,347 & $6,416,400$ \\
5 & 900 & 4,935 & $4,441,500$ \\
\hline \multicolumn{2}{l}{ Rata-rata } & 5,017 & $6,968,400$ \\
\hline \multicolumn{2}{l}{ Sumber : Olahan Data Primer, 2018 }
\end{tabular}

\section{Total Pendapatan Usahatani}

Pendapatan usahatani sebagai penerimaan dikurangi dengan biaya-biaya yang dikeluarkan untuk kegiatan usahatani, yaitu pendapatan yang diperoleh dari selisih penerimaan dan pengeluaran usahatani. 
Tabel 17 dan Tabel 18 menunjukkan bahwa Pendapatan yang paling tinggi terdapat pada petani padi sawah satu dengan total pendapatan sebesar Rp. 3,281,562 sedangkan pada petani padi sawah empat memperoleh pendapatan yang paling sedikit, sebesar $\mathrm{Rp}$. 751,085 dibandingkan dengan petani padi sawah dua yang memperoleh total pendapatan sebesar Rp. 2,097,403 petani padi sawah tiga dengan total pendapatan Rp. 2,445,508 dan petani padi sawah lima dengan total pendapatan sebesar Rp 1,594,081.

Besarnya biaya dari petani padi sawah empat yang mengakibatkan total pendapatan yang di terima menjadi paling sedikit, dapat pula dilihat dari jumlah biaya tenaga kerja petani padi sawah empat yang lebih besar dibandingkan dari ke empat petani padi sawah lainnya. Rata-rata penerimaan usahatani padi sawah untuk seluruh petani padi sawah yaitu Rp. 6,968,400.00, dengan biaya rata-rata yaitu Rp. 4,934,472.00 dan rata-rata pendapatan seluruh petani padi sawah sebesar Rp. 2.033.928.00.

\begin{tabular}{cccc}
\multicolumn{3}{c}{ Tabel 17. Total Pendapatan Usahatani Dalam Satu Kali } & Musim Tanam \\
\hline Responden & $\begin{array}{c}\text { Total } \\
\text { Penerimaan (TR) }\end{array}$ & $\begin{array}{c}\text { Total } \\
\text { Biaya (TC) }\end{array}$ & $\begin{array}{c}\text { Total } \\
\text { Pendapatan }(\boldsymbol{\pi})\end{array}$ \\
\hline 1 & 1,800 & 4,935 & $8,883,000$ \\
2 & 1,680 & 4,935 & $8,290,800$ \\
3 & 1,380 & 4,935 & $6,810,300$ \\
4 & 1,200 & 5,347 & $6,416,400$ \\
5 & 900 & 4,935 & $4,441,500$ \\
\hline Rata-rata & & 5,017 & $6,968,400$ \\
\hline Sumber : Olahan Data Primer, 2018 & &
\end{tabular}

Tabel 18. Pendapatan Petani Berdasarkan Luas Lahan

\begin{tabular}{cccc}
\hline Responden & $\begin{array}{c}\text { Luas Lahan } \\
\text { (Ha) }\end{array}$ & $\begin{array}{c}\text { Total Penerimaan } \\
(\mathbf{R p} / \mathbf{H a})\end{array}$ & $\begin{array}{c}\text { Total Biaya } \\
\text { (Rp/Ha) }\end{array}$ \\
\hline 1 & 0.50 & $17,766,000$ & $11,202,876$ \\
2 & 0.50 & $16,581,600$ & $12,386,794$ \\
3 & 0.40 & $17,025,750$ & $10,911,980$ \\
4 & 0.30 & $21,388,000$ & $18,884,383$ \\
5 & 0.25 & $17,766,000$ & $11,389,676$ \\
\hline Rata-rata & 0.39 & $18,105,470$ & $12,955,142$ \\
\hline Sumber : Olahan Data Primer, 2018 & &
\end{tabular}

\section{Kelayakan Usahatani}

Dengan menggunakan Analisis Return Cost Ratio dapat di ketahui apakah usahatani layak ataupun tidak layak untuk di usahakan. Dengan melakukan perbandingan antara total penerimaan dan total biaya maka akan diketahui apakah usahatani responden yang ada di Desa Tombatu Tiga Timur layak atau tidak untuk di lanjutkan proses usahatani yang sedang di usahakan.
Tabel 19. Hasil Analisis Return Cost Ratio

\begin{tabular}{cccc}
\hline Responden & $\begin{array}{c}\text { Total Penerimaan } \\
\text { (TR) }\end{array}$ & $\begin{array}{c}\text { Total Biaya } \\
\text { (TC) }\end{array}$ & $\begin{array}{c}\text { Return/Cost } \\
\text { R/C }\end{array}$ \\
\hline 1 & $8,883,000$ & $5,601,438$ & 1.59 \\
2 & $8,400,000$ & $6,193,397$ & 1.36 \\
3 & $6,900,000$ & $4,364,792$ & 1.58 \\
4 & $6,000,000$ & $5,665,315$ & 1.06 \\
5 & $4,500,000$ & $2,847,419$ & 1.58 \\
\hline Rata-rata & $6,936,600$ & $4,934,472$ & 1.43 \\
\hline
\end{tabular}

Sumber : Olahan Data Primer, 2018

Usahatani dapat dikatan menguntungkan bila nilai dari $\mathrm{R} / \mathrm{C}>1$. Tabel 19 menunjukkan bahwa nilai dari $\mathrm{R} / \mathrm{C}$ seluruh petani padi sawah di Desa Tombatu Tiga Timur Kecamatan Tombatu adalah > dari 1. Dengan demikian dapat disimpulkan bahwa usahatani padi sawah dari keseluruhan petani padi sawah yang ada di Desa Tombatu Tiga Timur Kecamatan Tombatu relatif menguntungkan. Dengan rata-rata Ratio adalah 1.43 .

\section{KESIMPULAN DAN SARAN}

\section{Kesimpulan}

Hasil penelitian menunjukkan bahwa;

1. Pendapatan rata-rata petani padi sawah di Desa Tombatu Tiga Timur Kecamatan Tombatu yaitu Rp. 2,033,928.00.

2. Dengan nilai $\mathrm{R} / \mathrm{C}$ Ratio yang di dapat petani padi sawah lebih dari 1 , yaitu 1.43 yang berarti usahatani padi sawah di Desa Tombatu Tiga Timur Kecamatan Kecamatan Tombatu menguntungkan sehingga layak untuk diusahakan.

\section{Saran}

Perlu dilakukan penambahan luas lahan produksi agar usahatani padi sawah yang ada di Desa Tombatu Tiga Timur dapat meningkatkan hasil pendapatan petani padi sawah.

\section{DAFTAR PUSTAKA}

Arsyad, S dan Rustiadi, E. 2008. Penyelamat Tanah, Air, Dan Lingkungan. Jakarta: Yayasan Obor Indonesia. 
Hamdan, 2003. Peta Pewilayahan komoditas pertanian Kabupaten Bengkulu Tengah Skala 1:50.000, Balai Pengkajian Teknologi Bengkulu: Bengkulu. 497 hal.
Koswara, S. 2009. Teknologi Pengolahan Telur. Ebook Pangan. http://www.itp. fateta .ipb.ac.id [21 Maret 2014]. 